\title{
METAL ACCUMULATION AND METALLOTHIONEIN INDUCTION IN THE SPOTTED DOGFISH SCYLIORHINUS CANICULA
}

\author{
De Boeck G., M. Eyckmans, I. Lardon, R. Bobbaers, A.K. Sinha and R. Blust \\ Laboratory of Ecophysiology, Biochemistry, and Toxicology, Department of Biology, University of \\ Antwerp, Groenenborgerlaan 171, 2020 Antwerp, Belgium \\ E-mail: gudrun.deboeck@ua.ac.be
}

\begin{abstract}
Metal toxicity has been studied extensively in teleost fish, but much less is known about the effect of metals on elasmobranchs. In a previous study, examining the effects of metals on an elasmobranch, silver appeared to be 10 times more toxic to Pacific spiny dogfish than to similarly sized marine teleosts and in fact, sensitivity approached that of freshwater teleosts. This sensitivity coincides with high $\mathrm{Ag}$ accumulation rates in gill and other tissues. As in teleosts, toxicity appeared to be related to osmoregulatory disturbance; however, in this elasmobranch, failure of the urea retention mechanism played an important role in the osmoregulatory disturbance. $\mathrm{Cu}$, which usually exert similar effects as Ag, did not induce this high toxicity or the high accumulation rates.
\end{abstract}

Despite the fact that normal background levels for metals in the marine environment are low, the differences in response between marine teleosts and elasmobranchs are intriguing. Therefore, the goals of the present study were to determine which metals showed high accumulation rates in another elasmobranch, Scyliorhinus canicula. For this purpose, we exposed the dogfish to 0.1 and $1 \mu \mathrm{M}$ of $\mathrm{Ag}$ or to $10 \mu \mathrm{M} \mathrm{Cd}, \mathrm{Cu}, \mathrm{Ni}$ or $\mathrm{Pb}$ for one week and measured metal accumulation, metallothionein induction, and parameters related to osmoregulation. 